\title{
Smoothened gene alterations in keratocystic odontogenic tumors
}

\author{
Zhang Rui ${ }^{1 \dagger}$, Peng Li-Ying ${ }^{1 \dagger}$, Qu Jia-Fei ${ }^{1}$, Hong Ying-Ying ${ }^{1}$, Chen Feng ${ }^{2^{*}}$ and Li Tie-Jun ${ }^{1 *}$
}

\begin{abstract}
Background: It has been widely demonstrated that the hedgehog pathway is strongly associated with basal cell carcinoma of the skin (NBCCS). To assess potential DNA alterations related to keratocystic odontogenic tumors (KCOTs), we sequenced smoothened (SMO) genes in 12 sporadic KCOTs.

Methods: Polymerase chain reaction (PCR), capillary electrophoresis and dideoxy chain-termination sequencing were used to examine potential DNA alterations in sporadic KCOTs.

Results: Five alterations in SMO genes were detected. Four of these mutations consisted of two synonymous and three missense mutations; two of which have not been reported to date (c.T776A, c.T1281G).

Conclusions: SMO genes may play an important role in the sonic hedgehog $(\mathrm{SHH})$ pathway and could also be responsible for generating KCOTs and NBCCS. However, their influence on SHH signaling remains to be elucidated.
\end{abstract}

Keywords: Keratocystic odontogenic tumor (KCOT), Hedgehog $(\mathrm{HH})$ signaling pathway, Gene mutation, SMO gene

\section{Background}

Odontogenic keratocyst (OKC) is an aggressive, cystic jaw lesion with strong growth potential and a high recurrence rate. In recent years, the World Health Organization (WHO) revised its name to keratocystic odontogenic tumor (KCOT). This reclassification is based on its aggressive behavior and high recurrence rate, emphasizing that KCOT is a benign tumor rather than a cyst [1-3]. Although the great majority of keratocysts occur in isolation as single, non-syndromic cysts, they may also present as multiple cysts as a feature of the nevoid basal cell carcinoma syndrome (Gorlin syndrome, OMIM\#109400) [4].

At present, there are many manuscripts that focus on the relationship between KCOT and PTCH1 (patched) gene mutations, demonstrating that PTCH1, the gene responsible for NBCCS, may also play an important role in sporadic KCOTs [5-8]. The PTCH1 gene is a tumor suppressor gene located at 9q22.32 [9]. A study of 14

\footnotetext{
* Correspondence: moleculecf@gmail.com; litiejun22@vip.sina.com ${ }^{\dagger}$ Equal contributors

${ }^{2}$ Central Laboratory, Peking University School and Hospital of Stomatology, 22 Zhongguancun Avenue South, Haidian District, Beijing 100081, China 22 Zhongguancun Avenue South, Haidian District, Beijing 100081, China
${ }^{1}$ Department of Oral Pathology, Peking University School and Hospital of Stomatology, 22 Zhongguancun Avenue South, Haidian District, Beijing 100081, China
}

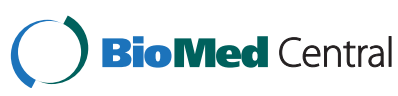

(c) 2014 Rui et al.; licensee BioMed Central Ltd. This is an Open Access article distributed under the terms of the Creative Commons Attribution License (http://creativecommons.org/licenses/by/4.0), which permits unrestricted use, distribution, and reproduction in any medium, provided the original work is properly credited. The Creative Commons Public Domain Dedication waiver (http://creativecommons.org/publicdomain/zero/1.0/) applies to the data made available in this article, unless otherwise stated.

patients with NBCCS-associated KCOTs and 29 patients with sporadic KCOTs indicated that mutations in transmembrane 2 (TM2) are closely related to the development of sporadic KCOTs [5].

The hedgehog $(\mathrm{HH})$ signaling pathway is a key regulator of embryonic development, controlling both cellular proliferation and cell fate. Binding of sonic hedgehog (SHH) to its receptor, patched (PTCH1), is believed to relieve normal inhibition by PTCH1 of smoothened (SMO), a seven-span transmembrane protein with homology to a G-protein-coupled receptor [10].

SMO is a tumor-related gene located at $7 \mathrm{q} 32.3$, contains 12 exons spanning approximately $24 \mathrm{~kb}$, and encodes a 787-amino-acid transmembrane glycoprotein [11]. Its receptor is a $G$ protein-coupled receptor that interacts with Patched, an important part of the $\mathrm{HH}$ signaling pathway during embryogenesis as well as adulthood $[12,13]$. The HH pathway has been demonstrated to play an important role in different development-related cancers [14-18], but the exact mechanism of action has not yet been elucidated. The protein generated by SMO is downstream of PTCH1; that is, the expression of PTCH1 restrains the activation of SMO, and thereby inhibits activation of the HH pathway [19-22]. Recent studies have highlighted the therapeutic value of SMO 
antagonists for the treatment of $\mathrm{HH}$-linked cancers $[22,23]$. SMO, the main activator of the HH pathway may serve as a catalyst during the generation of cysts, and therefore, genetic mutations of SMO are of great importance.

\section{Methods}

Tumor samples and clinical background

Fourteen KCOT samples with a definite diagnosis were acquired from clinical sources at Peking University School of Stomatology, Oral and Maxillofacial Surgery Department. Diagnoses were based on WHO classification of tumors: pathology and genetics of tumors of the head and neck [24]. All samples were from Chinese patients (eight males and six females). Ages varied from 10 to 58 years, with an average of 29.2 years. Experimental protocols used in this study were reviewed and approved by the Ethics Committee of the Peking University Health Science Center (Peking, China). Informed consent was obtained from all subjects.

\section{DNA isolation and mutation analysis}

Genomic DNAs from epithelial cells and interstitial cells of tumors were isolated using a QIAamp DNA Mini kit (Qiagen, Hilden, American) according to the manufacturer's instructions. DNA was quantified using a Nanodrop (Thermo Fischer, Wilmington, DE). SMO (NM_005631.4) coding sequences were determined using polymerase chain reaction (PCR) and 1\% agarose gel electrophoresis. Thirteen pairs of primers covering the entire coding sequences and a few nucleotides into the intron sequences on both ends of SMO are described in Table 1. PCRs were performed on a PTC-100 (MJ Research, Watertown, MA, USA) in a final volume of $30 \mu \mathrm{L}$ containing approximately 100-ng template DNA, $200 \mu \mathrm{mol} / \mathrm{L}$ dNTPs, $0.2-0.4 \mu \mathrm{mol} / \mathrm{L}$ each primer, 1.25 U ExTaq polymerase (TaKaRa, Dalian, China), and 10X PCR buffer $(50 \mathrm{mmol} / \mathrm{L} \mathrm{KCl}, 10 \mathrm{mmol} / \mathrm{L}$ Tris- $\mathrm{HCl}$, $\mathrm{pH} 9.0$, and $1.5 \mathrm{mmol} / \mathrm{L} \mathrm{MgCl}_{2}$ ). Exon 1, exon 12a and exon $12 \mathrm{~b}$ of the SMO gene were amplified by a touchdown (TD) PCR technique (Table 1). For example, TD $65-56^{\circ} \mathrm{C}$ was performed as follows: an initial denaturation step at $95^{\circ} \mathrm{C}$ for $5 \mathrm{~min}$, followed by 40 cycles at $94^{\circ} \mathrm{C}$ for $30 \mathrm{~s}, 30 \mathrm{~s}$ at an annealing temperature decreasing from $65^{\circ} \mathrm{C}$ to $56^{\circ} \mathrm{C}$ (decrease of $1^{\circ} \mathrm{C}$ each 2 cycles, 20 cycles at $55^{\circ} \mathrm{C}$ ), $30 \mathrm{~s}$ at $72^{\circ} \mathrm{C}$, and a final extension step at $72^{\circ} \mathrm{C}$ for $10 \mathrm{~min}$. The specificity of amplified products was confirmed by $2 \%$ agarose gel electrophoresis. PCR products were purified by Life Technologies (Applied Biosystems, USA) and sequenced by an ABI 3730xl DNA sequencer (Applied Biosystems, USA). Both forward and reverse strands were sequenced. Any mutation detected was confirmed using both forward and reverse primers.

\section{Statistical analysis}

Experimental data were analyzed using the SPSS ver. 10.0 software and are presented as means \pm standard deviation (SD) using statistical methods such as a $t$-test, analysis of bivariate correlation, etc. A P value $<0.05$ was considered to indicate statistical significance. Results are representative of two independent experiments.

\section{Results and discussion}

\section{Hedgehog $(\mathrm{HH})$ signaling pathway}

Hedgehog $(\mathrm{HH})$ is a signal transduction pathway closely related to cell growth and differentiation, and plays a vital role in embryonic development. Mutation or abnormal

Table 1 PCR conditions of SMO exons

\begin{tabular}{|c|c|c|c|c|c|}
\hline Exon & Size(bp) & $\begin{array}{l}\text { Forward primer } \\
\left.\text { sequence ( } 5^{\prime} \text { to } 3^{\prime}\right)\end{array}$ & $\begin{array}{l}\text { Reverse primer } \\
\left.\text { sequence ( } 5^{\prime} \text { to } 3^{\prime}\right)\end{array}$ & Reference & $\begin{array}{l}\text { Annealing } \\
\text { temperature }\left({ }^{\circ} \mathrm{C}\right)\end{array}$ \\
\hline 1 & 391 & GGGCTGCTGCTGCTGCTG & GTCCCCGCCCTCTCCAAAACT & Sun et al., 2008 [25] & TD60 50 \\
\hline 2 & 283 & AAGAACTGTCCTGCCCAGATG & CCACTGGACCCTGCCCTATAC & Wang et al., 2013 [12] & 63 \\
\hline 3 & 305 & AATAATTTGCCAAGCCAGCC & CTTCTGATCATGACCCTTCCC & Wang et al., 2013 [12] & 63 \\
\hline 4 & 256 & AGGGTCATGATCAGAAGGGTC & AGTATGCAGTAGGGCAGAGCC & Wang et al., 2013 [12] & 63 \\
\hline 5 & 302 & CTGACTTCTGGGAACCTCCAG & GACAGAAGGTGGGTTACTGGC & Wang et al., 2013 [12] & 63 \\
\hline 6 & 206 & GTGGCGCAGGTATAGTGACTG & GCCCTATAGGAGCTAGCTGGG & Wang et al., 2013 [12] & 63 \\
\hline 7 & 175 & GACTCCAGAGCCTTAGGACCC & TCCCTATGGCTAACTTGTCCC & Wang et al., 2013 [12] & 63 \\
\hline 8 & 196 & AAGCAGTTCTTGGACTGAGCC & CCATCCATTGAATCTGCTGTC & Wang et al., 2013 [12] & 55 \\
\hline 9 & 379 & AGTTGGAAGCTGCAGTGGG & CAAGGCTGTGCTAGAGGCAG & Wang et al., 2013 [12] & 63 \\
\hline 10 & 228 & CTCTGGAAAGAATGGCATCG & TTCCAAATAATCTGTGTGCCC & Wang et al., 2013 [12] & 55 \\
\hline 11 & 215 & AATGGCACTGACTATGGGAGG & CCACTCTTCAGATCCTCTGGG & Wang et al., 2013 [12] & 63 \\
\hline $12 \mathrm{a}$ & 292 & GAGCCAGGGCCCCAGGCTCGT & ACGCTCCCTGTCGGCAAGAGT & Sun et al., 2008 [25] & TD65-56 \\
\hline $12 b$ & 315 & AGTACCATTCCTCGACTGCCT & GGTATTGGTTCCTCTCTITCC & Sun et al., 2008 [25] & TD65-56 \\
\hline
\end{tabular}


expression of components of this pathway will lead to various developmental defects and/or tumors. Altered $\mathrm{HH}$ signaling is implicated in the development of approximately 20-25\% of all cancers, especially those of soft tissues [26]. These findings also suggest that proteins of the $\mathrm{HH}$ signaling pathway are predominantly located within the epithelial components of glandular odontogenic cysts (GOCs) and dentigerous cysts (DCs). Therefore, the $\mathrm{HH}$ signaling pathway may play an important role in the formation of epithelial lining [27]. The discovery of oncogenic mutations in the $\mathrm{HH}$ and mitogen-activated protein kinase (MAPK) pathways in over $80 \%$ of ameloblastomas, locally destructive odontogenic tumors of the jaw, was reported in 2014 by genomic analysis of archival material. Mutations in SMO are common in ameloblastomas of the maxilla, whereas BRAF mutations are predominant in tumors of the mandible [28]. In addition, $\mathrm{SHH}$ subgroup medulloblastomas are genetically distinct in infants, children and adults [29]. Most meningiomas have simple genomes, with fewer mutations, rearrangements and copy-number alterations than reported in other adult tumors. However, several meningiomas harbor more complex patterns of copy-number changes and rearrangements, including one tumor with chromothripsis. A subset of meningiomas lacking NF2 alterations harbored recurrent oncogenic mutations in AKT1 (p.Glu17Lys) and SMO (p.Trp535Leu), and exhibited immunohistochemical evidence of activation of these pathways [11]. In another study, SMO mutations, which activate the $\mathrm{SHH}$ signaling pathway, were identified in $\sim 5 \%$ of non-NF2 mutant meningiomas. Collectively, these findings identify distinct meningioma subtypes [30]. Moreover, some findings provide a rationale to explore the use of SMO and BCL2 inhibitors as adjuvant therapy for treatment of DLBCL of the GC type [31]. The expression of SMO in NPC is generally high, whereas expression of PTCH-1 is relatively low. Downregulation of PTCH1 and upregulation of SMO may cause abnormal activation of the $\mathrm{HH}$ signaling pathway in NPC, albeit that the genesis and development of NPC may be associated with abnormal activation of $\mathrm{HH}$ signaling [32]. The $\mathrm{HH}$ signaling pathway is controlled by PTCH1 and SMO, which are located on the target cell's membrane. As the receptor of sonic hedgehog $(\mathrm{SHH})$, the PTCH1 gene $(51 \mathrm{~kb})$ encodes a 12-transmembrane-domain protein (total, 1,447 amino acids). There are two homologous genes in humans, PTCH2 and PTCH1, which negatively regulate SMO, a G-protein-coupled receptor, through SHH. SMO belongs to the $\mathrm{G}$ protein-coupled receptor FZ/SMO superfamily, containing a field that crosses the cell membrane seven times. Without a ligand ( $\mathrm{SHH}), \mathrm{PTCH}$ and SMO form an inhibitory compound, restraining signal transduction throughout the entire pathway. However, when $\mathrm{SHH}$ binds to PTCH1, SMO escapes from the inhibition by PTCH1, resulting in enhanced expression of downstream target genes, including the GLI superfamily [33]. As shown by numerous researchers, abnormal activation of the $\mathrm{HH}$ signaling pathway is closely related to the development of a variety of tumors, and both PTCH1 and SMO play a critical role in this pathway.

The $\mathrm{HH}$ signaling cascade is highly conserved and involved in the development of disease throughout evolution. Nevertheless, compared with other pathways, our mechanistic understanding of $\mathrm{HH}$ signal transduction is remarkably incomplete. In the absence of ligand, the $\mathrm{HH}$ receptor Patched (Ptc), represses the key signal transducer Smoothened (Smo) through an unknown mechanism. HH binding to Ptc alleviates this repression, causing Smo redistribution to the plasma membrane, phosphorylation and subsequent opening of the Smo cytoplasmic tail and Smo oligomerization. However, the order and interdependence of these events are poorly understood. We have mathematically modeled and simulated Smo activation for two alternative modes of activation, with Ptc primarily affecting either Smo localization or phosphorylation. Here, we show that Smo localization to the plasma membrane is sufficient for phosphorylation of the cytoplasmic tail in the presence of Ptc. Using fluorescence cross-correlation spectroscopy (FCCS), we also demonstrated that inactivation of Ptc by $\mathrm{HH}$ induces Smo clustering irrespective of Smo phosphorylation. Our observations therefore support a model of $\mathrm{HH}$ signal transduction whereby subcellular localization of Smo, and not phosphorylation, is the primary target of Ptc function [31].

Several studies [34-36] have confirmed that the PTCH1 gene is a tumor suppressor; this suggests that its mutation increases the likelihood of developing cancer, although few reports regarding the relationship between SMO and KCOT have been published.

\section{SMO mutations}

Coding variants of SMO were identified following our analysis, and the mutations are listed in Table 2. The four SMO mutations detected were distributed on five exons (exons 2, 3, 5, 6, and 10), of which there were two synonymous mutations and three missense mutations.

The first alteration was located at nucleotide position 776 of exon 2, a heterozygous mutation from $\mathrm{T}$ to $\mathrm{A}$ (Figure 1A); this alteration has not yet been reported by other researchers. We determined that 9 of 12 KCOT patients have this alteration. After comparing the protein amino acid sequences of human, rice, mouse, and Drosophila (Figure 2), we concluded that this amino acid is relatively conserved. Meanwhile, following Genomics online software SIFT [37] (http://sift.jcvi.org/) analysis, we concluded that the amino acid change results in a negative and damaging effect on the protein (Provean Preduction: 
Table 2 SMO mutations in 12 sporadic and 19 NBCCS-associated KCOTs

\begin{tabular}{|c|c|c|c|c|c|c|c|c|}
\hline Histology & Sample ID & Exon/intron & $\begin{array}{l}\text { Nucleotide } \\
\text { definition }\end{array}$ & $\begin{array}{l}\text { Amino acid } \\
\text { definition }\end{array}$ & $\begin{array}{l}\text { dbSNP rs\# } \\
\text { cluster ID }\end{array}$ & MAF & Class & Function \\
\hline$S^{*}$ & $\begin{array}{l}\mathrm{K} 1, \mathrm{~K} 2, \mathrm{~K} 4, \mathrm{~K} 5, \mathrm{~K} 6, \mathrm{~K} 7, \\
\mathrm{~K} 8, \mathrm{~K} 10, \mathrm{~K} 11\end{array}$ & Exon 2 & c.T776A & p.Phe166lle & - & - & Missense & Unknown \\
\hline S & K7 & Exon 3 & c.A862G & p. $=(194) \mathrm{Glu}$ & rs56334250 & 0.0266 & Synonymous & Polymorphism \\
\hline S & K4 & Exon 5 & c.T1281G & p.Val334Gly & - & - & Missense & Unknown \\
\hline S & $\begin{array}{l}\mathrm{K} 2, \mathrm{~K} 3, \mathrm{~K} 4, \mathrm{~K} 5, \mathrm{~K} 6, \mathrm{~K} 7, \\
\mathrm{~K} 8, \mathrm{~K} 9, \mathrm{~K} 10, \mathrm{~K} 11, \mathrm{~K} 12\end{array}$ & Exon 6 & c.G1444C & p. $=(388)$ Gly & rs2228617 & 0.2277 & Synonymous & Polymorphism \\
\hline$N^{*}$ & $\begin{array}{l}\text { N1, N2, N3, N4, N5, N6, } \\
\text { N7, N8, N9, N10, N11, } \\
\text { N12, N13, N14, N15, } \\
\text { N16, N17, N18, N19, }\end{array}$ & Exon 6 & c.G1444C & p. $=(388)$ Gly & rs2228617 & 0.2277 & Synonymous & Polymorphism \\
\hline S & K1 & Exon 10 & c.G2049C & p.Ser590Thr & rs114406835 & 0.010 & Missense & Polymorphism \\
\hline
\end{tabular}

${ }^{*} \mathrm{~S}=$ sporadic, $\mathrm{N}=\mathrm{NBCCS}$-associated.

Deleterious; Sift Preduction: Damaging). Through further analysis, we discovered that the amino acid is located in a cysteine-rich domain (CRD) of the Smoothened receptor (Smo) integral membrane protein. The CRD is one of the key players in the $\mathrm{HH}$ signaling pathway, and is critical for development, cell growth and migration, as well as stem cell maintenance. The CRD of Smo is conserved in vertebrates and can also be identified in invertebrates. The precise function of the CRD in Smo is unknown. Mutations in the Drosophila CRD disrupt Smo activity in vivo, while deletion of the CRD in mammalian cells does not appear to affect Smo overexpression [38-40]. Therefore, we believe that this amino acid may tremendously impact development, cell growth and migration, as well as stem cell maintenance. It is important to note that the peak of this alteration is different from mutations at other positions. For example, the peak of $\mathrm{A}$ is relatively lower than $\mathrm{T}$, but not as high as half of T. According to a recent report [41], this may be due to the heterogeneity of tumors in issues we detected, indicating that some cells have mutated while others remain unchanged.

The second alteration, a heterozygous mutation from A to G, was located at nucleotide position 862 of exon 3 (Figure 1B) but does not result in an amino acid change at p.G194. The third mutation (c.G1444C, with G/C alleles) was identified in seven tumors (Figure 1C), but does not result in an amino acid change at p.G388. One interesting fact about this synonymous mutation is, with the exception of one sporadic KCOT, all other samples (including sporadic and NBCCS-associated) were identified with this mutation, of which 17 were homozygous and 13 were heterozygous. The frequency of $G$ reached a high of 0.7581, which is far higher than the statistic reported in the single-nucleotide polymorphism (SNP) database curated by the National Centre for Biotechnology Information (NCBI) and the 1000 Genomes Project ( minor allele frequency $[\mathrm{MAF}]=0.2277$ ). This mutation has been reported in many other cell lines associated with mesothelioma, such as MSTO-211H, NCI-H28, JU77, LO68, NO36, ONE58, and STY51 [42]. Therefore, it is highly likely that this mutation plays a significant role in the occurrence of tumors. However, whether this mutation is related to KCOTs should be determined.

One of the missense mutations (c.G2049C, with G/C alleles), which has been reported previously, has unknown functional implications (Figure 1D). This mutation leads to an amino acid change at p.Ser590Thr; it is important to note that both Val and Gly can be phosphorylated. Meanwhile, SIFT software analysis revealed that an interactive mutation between these amino acids is neutral and tolerated (Table 3). In fact, this altered amino acid is located within the intracellular loops of Smoothened, which may be critically related to downstream proteins, and subsequently impact the functioning of SMO, thereby impacting activation of the $\mathrm{HH}$ signaling pathway [43].

The missense mutation (c.T1281G, with T/C alleles) has not been reported previously (Figure 1E). This mutation leads to an amino acid change (p.Val334Gly) located on the first extracellular loop of Smoothened, which is closely associated with the function of SMO. Functional studies on transmembrane regions are restricted by technological conditions, but according to the SIFT software (Table 3), mutation of this amino acid leads to damaging changes in the protein; therefore, we believe that this mutation strongly impacts disease occurrence. Additional studies are required to determine whether this mutation causes functional changes in the SMO gene.

The mode of action between the SMO and PTCH genes has yet to be elucidated, but recent studies have shown that any missing gene in yeast will impose pressure on the cell to compensate, thereby leading to additional genetic mutations [44]. Most SMO gene mutations 


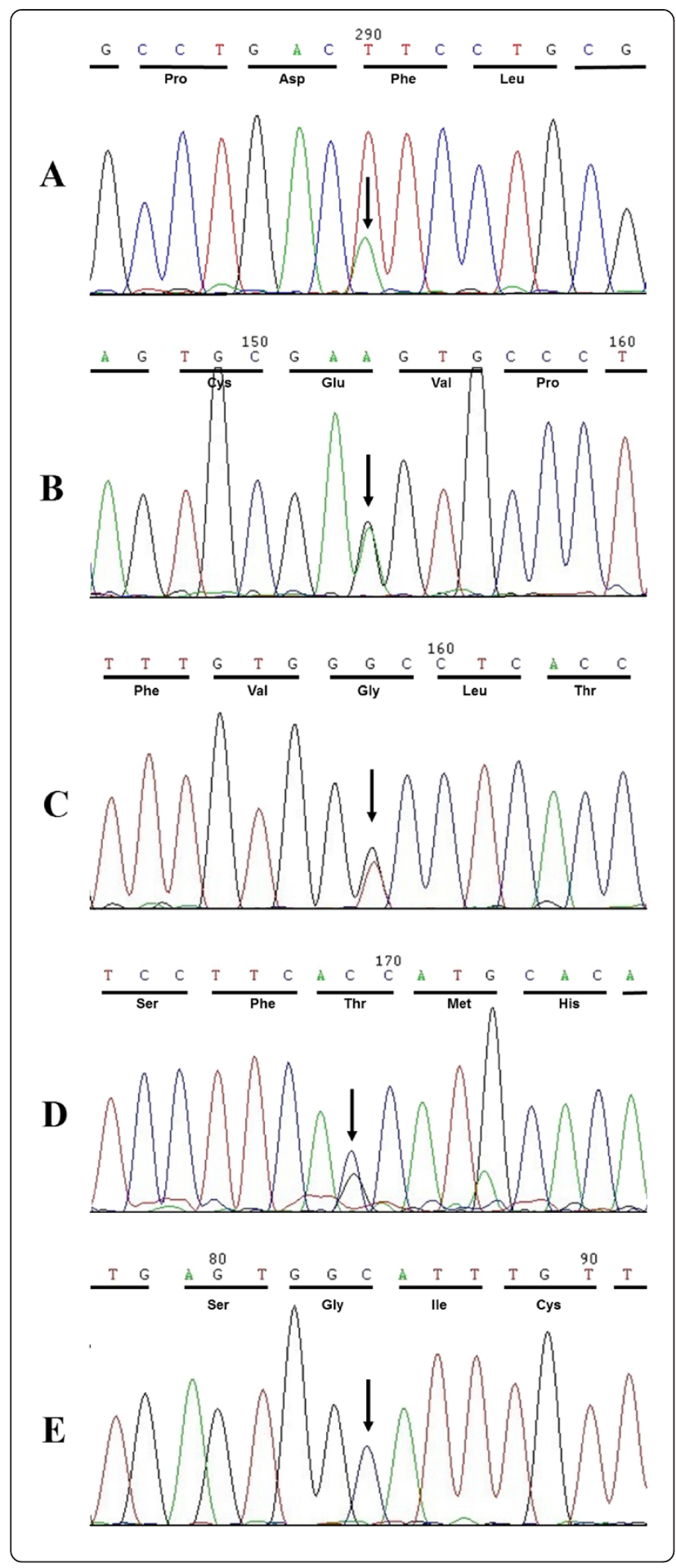

Figure $1 \mathrm{SMO}$ missense mutation in sporadic KCOTs. A. This alternation at nucleotide position 776 of exon 2 is a heterozygous mutation from $\mathrm{T}$ to $\mathrm{A}$ and causes the p.Phe166lle mutation. B. This alternation at nucleotide position 862 of exon 3 is a heterozygous mutation from $A$ to $G$. However, this nucleotide change does not result in amino acid change ( $p .=(194) \mathrm{Glu})$. Minor allele frequency $(\mathrm{MAF})=0.0266$. C. This alternation at nucleotide position 1444 of exon 6 was identified in seven tumors. Among 31 patients sequenced, 17 are homozygous and 13 are heterozygous at this site. This nucleotide change does not result in an amino acid change (p. = (388) Gly). MAF $=0.2277$. D. This alternation at nucleotide position 2049 of exon 10 is a heterozygous mutation from $G$ to $C$ and causes the $p$. Ser590Thr mutation. E. This alternation at nucleotide position 1281 of exon 5 is a heterozygous mutation from $T$ to $C$ and causes the p.Val334Gly mutation.

detected are serious alterations, such as missense and synonymous mutations, while frameshift and nonsense mutations have not been detected. Therefore, we believe that the SMO gene mutation may serve as a driving force in patients with KCOTs. To compensate for the defects caused by the SMO mutation, PTCH1 causes the same signaling pathway to mutate, leading to mutation(s) in the PTCH gene. This conjecture needs further work to confirm. In most cases, people believe that tumor growth is driven by the "latest" cancer cell subsets because they carry most cancer mutations. However, many mutations exist at a low frequency, suggesting that tumors contain many subclones the relationships among which are still unclear. A recent report examining the heterogeneity of breast cancer [41] showed that stem cells in breast epithelia could differentiate into luminal and basal cells, which constitute the epithelia. Some also believe that breast neoplasms induced through Wnt1 overexpression

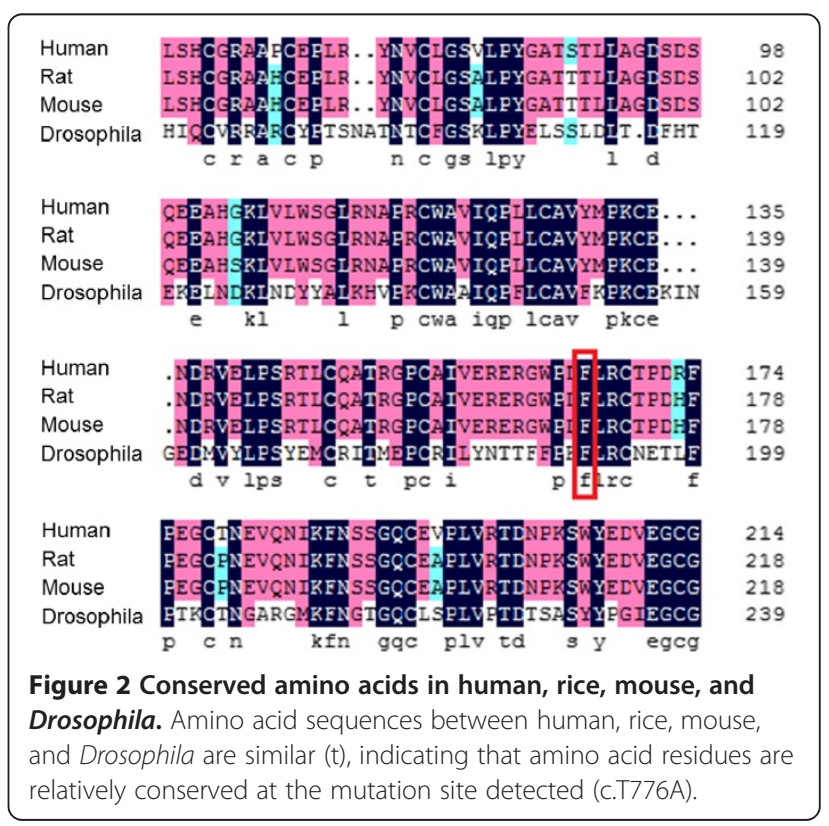


Table 3 PROVEAN human protein batch result

\begin{tabular}{|c|c|c|c|c|c|c|c|c|}
\hline \multirow{2}{*}{$\begin{array}{l}\text { Variation } \\
\text { Row_No. }\end{array}$} & \multicolumn{4}{|c|}{ Protein sequence change } & \multicolumn{2}{|c|}{ PROVEAN prediction } & \multicolumn{2}{|c|}{ Sift prediction } \\
\hline & Protein_ID & Position & Residue_REF & Residue_ALT & Score & $\begin{array}{l}\text { Prediction } \\
\text { (cutoff }=-2.5 \text { ) }\end{array}$ & Score & $\begin{array}{l}\text { Prediction } \\
\text { (cutoff }=0.05 \text { ) }\end{array}$ \\
\hline 1 & NP_005622.1 & 166 & $\mathrm{~F}$ & I & -5.385 & Deleterious & 0.002 & Damaging \\
\hline 2 & NP_005622.1 & 334 & V & G & -5.063 & Deleterious & 0.003 & Damaging \\
\hline 3 & NP_005622.1 & 590 & S & $\mathrm{T}$ & -1.487 & Neutral & 0.219 & Tolerated \\
\hline
\end{tabular}

Changes at amino acids 166 and 344 cause a deleterious alteration and a damaging result. The change at amino acid position 590 is relatively neutral and tolerated by the protein.

are derived from this cell type. Paracrine interaction between two cell types, which is driven by signaling molecules, and its short distance, maintains co-existence of two types of pedigree. Only luminal cells can produce Wnt1, whereas basal cells rely on this protein to proliferate. Wnt1 induces the Hras gene in basal cells of breast neoplasms, which may contain a mutation that drives cancer progression, but this mutation has not yet been detected in cancerous cells in the lumen. There is cooperation between basal and luminal cell clones; this cooperation is necessary for Wnt1 to drive two types of cells in tumors. In addition, KCOTs occur during the early stages of dental epithelial formation, during which dental lamina and its residential, epithelium and stroma interact with others during growth, subsequently inducing differentiation. Therefore, we hypothesize that mutation of some genes in the subcutaneous interstitial tissue may impose pressure on epithelial genes to compensate for the defect, and that the SMO mutation may play a critical role in this process. However, additional studies are needed for confirmation.

As we know, the hedgehog signaling pathway is being suggested to be a drug target for cancer therapy for its activation in human cancers [45-47]. Therefore, we think the two newly identified SMO mutations deserve to be further investigated for their therapeutic application in cancer treatment.

\section{Conclusions}

Following the analysis of SMO gene mutations and combining our results with similar studies, we conclude that SMO plays an important role in the $\mathrm{HH}$ signaling pathway and may be responsible for the development of KCOTs and NBCCS. However, further research focusing on the mechanism of their influence on the $\mathrm{SHH}$ signaling pathway is required.

Competing interests

The authors declare that they have no competing interests.

\section{Authors' contributions}

FC conceived and designed the research. JFQ and YYH provided samples. RZ and LYP performed the experiments, and collected, analyzed and interpreted the data. LYP wrote the manuscript, and edited tables and figures. RZ edited the manuscript, tables and figure legends. FC and TJL reviewed and edited the manuscript. All authors read and approved the final manuscript.

\section{Acknowledgments}

We gratefully acknowledge the patients who participated in this study and Dr. Qian Zhang for her technical assistance. This study was supported by grants from the National Natural Science Foundation of China (nos. 81030018,30872900 and 81200762).

The English in this document has been checked by at least two professional editors, both native speakers of English. For a certificate, please see: http:// www.textcheck.com/certificate/GilDRH.

Received: 18 June 2014 Accepted: 29 August 2014

Published: 5 September 2014

\section{References}

1. Bhargava D, Deshpande A, Pogrel MA: Keratocystic odontogenic tumour (KCOT)-a cyst to a tumour. Oral Maxillofac Surg 2012, 16(2):163-170.

2. Nayak MT, Singh A, Singhvi A, Sharma R: Odontogenic keratocyst: what is in the name? J Nat SC Biol Med 2013, 4(2):282-285.

3. Li TJ: The odontogenic keratocyst: a cyst, or a cystic neoplasm? J Dent Res 2011, 90(2):133-142.

4. Gu XM, Zhao HS, Sun LS, Li TJ: PTCH mutations in sporadic and gorlin-syndrome-related odontogenic keratocysts. J Dent Res 2006, 85(9):859-863.

5. Guo YY, Zhang JY, Li XF, Luo HY, Chen F, Li TJ: PTCH1 gene mutations in keratocystic odontogenic tumors: a study of 43 Chinese patients and a systematic review. PLOS ONE 2013, 8(10):e77305.

6. Pan S, Dong Q, Sun LS, Li TJ: Mechanisms of inactivation of PTCH1 gene in nevoid basal cell carcinoma syndrome: modification of the two-hit hypothesis. Clin Cancer Res 2010, 16(2):442-450.

7. Li TJ, Yuan JW, Gu XM, Sun LS, Zhao HS: PTCH germline mutations in Chinese nevoid basal cell carcinoma syndrome patients. Oral Dis 2008, 14(2):174-179.

8. Musani V, Sabol M, Car D, Ozretic P, Kalafatic D, Maurac I, Oreskovic S, Levanat S: PTCH1 gene polymorphisms in ovarian tumors: potential protective role of c.3944T allele. Gene 2013, 517(1):55-59.

9. Hahn H, Wicking C, Zaphiropoulous PG, Gailani MR, Shanley S, Chidambaram A, Vorechovsky I, Holmberg E, Unden AB, Gillies S, Hahn H, Wicking C, Zaphiropoulous PG, Gailani MR, Shanley S, Chidambaram A, Vorechovsky I, Holmberg E, Unden AB, Gillies S, Negus K, Smyth I, Pressman C, Leffell DJ, Gerrard B, Goldstein AM, Dean M, Toftgard R, Chenevix-Trench G, Wainwright B, Bale AE: Mutations of the human homolog of Drosophila patched in the nevoid basal cell carcinoma syndrome. Cell 1996, 85(6):841-851

10. Stone DM, Hynes M, Armanini M, Swanson TA, Gu Q, Johnson RL, Scott MP, Pennica D, Goddard A, Phillips H, Noll M, Hooper JE, de Sauvage F, Rosenthal A: The tumour-suppressor gene patched encodes a candidate receptor for Sonic hedgehog. Nature 1996, 384(6605):129-134.

11. Brastianos PK, Horowitz PM, Santagata S, Jones RT, McKenna A, Getz G, Ligon KL, Palescandolo E, Van Hummelen P, Ducar MD, Raza A, Sunkavalli A, Macconaill LE, Stemmer-Rachamimov AO, Louis DN, Hahn WC, Dunn IF, Beroukhim R: Genomic sequencing of meningiomas identifies oncogenic SMO and AKT1 mutations. Nat Genet 2013, 45(3):285-289.

12. Wang C, Wu H, Katritch $V$, Han GW, Huang XP, Liu W, Siu FY, Roth BL, Cherezov V, Stevens RC: Structure of the human smoothened receptor bound to an antitumour agent. Nature 2013, 497(7449):338-343.

13. Ruat $M$, Hoch L, Faure $H$, Rognan D: Structure of the smoothened receptor. Med Sci 2013, 29(10):855-860.

14. Jiang J, Hui CC: Hedgehog signaling in development and cancer. Dev Cell 2008, 15(6):801-812. 
15. Amakye D, Jagani Z, Dorsch M: Unraveling the therapeutic potential of the Hedgehog pathway in cancer. Nat Med 2013, 19(11):1410-1422.

16. Yang W, Wang J, Moore DC, Liang $H$, Dooner M, Wu Q, Terek R, Chen Q, Ehrlich MG, Quesenberry PJ, Neel BG: Ptpn11 deletion in a novel progenitor causes metachondromatosis by inducing hedgehog signalling. Nature 2013, 499(7459):491-495.

17. Ren Y, Cowan RG, Migone FF, Quirk SM: Overactivation of hedgehog signaling alters development of the ovarian vasculature in mice. Biol Reprod 2012, 86(6):174.

18. Jorgensen TJ, Ruczinski I, Yao Shugart $Y$, Wheless $L$, Berthier Schaad $Y$, Kessing B, Hoffman-Bolton J, Helzlsouer KJ, Kao WH, Francis L, Alani RM, Strickland PT, Smith MW, Alberg AJ: A population-based study of hedgehog pathway gene variants in relation to the dual risk of basal cell carcinoma plus another cancer. Cancer Epidemiol 2012, 36(5):e288-e293.

19. Yang $C$, Chen W, Chen $Y$, Jiang J: Smoothened transduces Hedgehog signal by forming a complex with Evc/Evc2. Cell Res 2012, 22(11):1593-1604

20. Shen F, Cheng L, Douglas AE, Riobo NA, Manning DR: Smoothened is a fully competent activator of the heterotrimeric $\mathrm{G}$ protein $\mathrm{G}(\mathrm{i})$. Mol Pharmacol 2013, 83(3):691-697.

21. Myers BR, Sever N, Chong YC, Kim J, Belani JD, Rychnovsky S, Bazan JF, Beachy PA: Hedgehog pathway modulation by multiple lipid binding sites on the smoothened effector of signal response. Dev Cell 2013, 26(4):346-357.

22. Mao J, Fan PH, Ma W, Zhang QQ, Wang B, Fan SJ, Li LH: Down-regulation of Smoothened gene expression inhibits proliferation of breast cancer stem cells. Zhonghua Bing Li Xue Za Zhi / Chinese Journal of Pathology 2013, 42(4):262-266

23. Ruat M, Hoch L, Faure H, Rognan D: Targeting of Smoothened for therapeutic gain. Trends Pharmacol Sci 2014, 35(5):237-246.

24. Thompson L: World Health Organization classification of tumours: pathology and genetics of head and neck tumours. Ear Nose Throat $J$ 2006, 85(2):74

25. Sun LS, Li XF, Li TJ: PTCH1 and SMO gene alterations in keratocystic odontogenic tumors. J Dent Res 2008, 87(6):575-579.

26. Zhang X, Harrington N, Moraes RC, Wu MF, Hilsenbeck SG, Lewis MT: Cyclopamine inhibition of human breast cancer cell growth independent of Smoothened (Smo). Breast Cancer Res Treat 2009, 115(3):505-521.

27. Zhang L, Sun ZJ, Chen XM, Chen Z: Immunohistochemical expression of SHH, PTC, SMO and GLI1 in glandular odontogenic cysts and dentigerous cysts. Oral Dis 2010, 16(8):818-822.

28. Sweeney RT, McClary AC, Myers BR, Biscocho J, Neahring L, Kwei KA, Qu K, Gong X, Ng T, Jones CD, Varma S, Odegaard Jl, Sugiyama T, Koyota S, Rubin BP, Troxell ML, Pelham RJ, Zehnder JL, Beachy PA, Pollack JR, West RB: Identification of recurrent SMO and BRAF mutations in ameloblastomas. Nat Genet 2014, 46(7):722-5.

29. $\bigotimes$ : Genetic mutations predict SMO inhibitor response in $\mathrm{SHH}$ medulloblastoma. Canc discov 2014, 4(5):509.

30. Clark VE, Erson-Omay EZ, Serin A, Yin J, Cotney J, Ozduman K, Avsar T, Li J, Murray PB, Henegariu O, Yilmaz S, Günel JM, Carrión-Grant G, Yilmaz B, Grady C, Tanrikulu B, Bakircioğlu M, Kaymakçalan H, Caglayan AO, Sencar L, Ceyhun E, Atik AF, Bayri Y, Bai H, Kolb LE, Hebert RM, Omay SB, Mishra-Gorur K, Choi M, Overton JD, Holland EC, et al: Genomic analysis of non-NF2 meningiomas reveals mutations in TRAF7, KLF4, AKT1, and SMO. Science 2013, 339(6123):1077-1080

31. Kunkalla KLY, Qu C, Leventaki V, Agarwal NK, Singh RR, Vega F: Functional inhibition of $B C L 2$ is needed to increase the susceptibility to apoptosis to SMO inhibitors in diffuse large B-cell lymphoma of germinal center subtype. Ann Hematol 2013, 92:777-787.

32. Xiao BY, Dang H, Gan JY, Cai Q, Zhang GP, Chang H: Expression of PTCH-1 and SMO mRNA in nasopharyngeal carcinoma. Xi Bao Yu Fen Zi Mian Yi Xue Za Zhi 2010, 26(10):955-958.

33. Alcedo J, Ayzenzon M, Von Ohlen T, Noll M, Hooper JE: The Drosophila smoothened gene encodes a seven-pass membrane protein, a putative receptor for the hedgehog signal. Cell 1996, 86(2):221-232.

34. Levanat S, Kappler R, Hemmerlein B, Doring P, Musani V, Komar A, Oreskovic S, Pavelic B, Hahn H: Analysis of the PTCH1 signaling pathway in ovarian dermoids. Int J Mol Med 2004, 14(5):793-799.

35. Honma M, Ohishi $Y$, Uehara J, Ibe $M$, Kinouchi $M$, Ishida-Yamamoto A, lizuka $\mathrm{H}$ : A novel PTCH1 mutation in a patient of nevoid basal cell carcinoma syndrome. J Dermatol Sci 2008, 50(1):73-75.
36. Hime GR, Lada H, Fietz MJ, Gillies S, Passmore A, Wicking C, Wainwright BJ: Functional analysis in Drosophila indicates that the NBCCS/PTCH1 mutation G509V results in activation of smoothened through a dominant-negative mechanism. Dev Dyn 2004, 229(4):780-790.

37. Hu J, Ng PC: SIFT indel: predictions for the functional effects of amino acid insertions/deletions in proteins. PLOS ONE 2013, 8(10):e77940.

38. Marchler-Bauer A, Lu S, Anderson JB, Chitsaz F, Derbyshire MK, DeWeeseScott C, Fong JH, Geer LY, Geer RC, Gonzales NR, et al: CDD: a conserved domain database for the functional annotation of proteins. Nucleic Acids Res 2011, 39(Database issue):D225-D229.

39. Marchler-Bauer A, Anderson JB, Chitsaz F, Derbyshire MK, DeWeese-Scott C, Fong JH, Geer LY, Geer RC, Gonzales NR, Gwadz M, He S, Hurwitz DI, Jackson JD, Ke Z, Lanczycki CJ, Liebert CA, Liu C, Lu F, Lu S, Marchler GH, Mullokandov M, Song JS, Tasneem A, Thanki N, Yamashita RA, Zhang D, Zhang N, Bryant SH: CDD: specific functional annotation with the conserved domain database. Nucleic Acids Res 2009, 37(Database issue):D205-D210.

40. Marchler-Bauer A, Bryant SH: CD-Search: protein domain annotations on the fly. Nucleic Acids Res 2004, 32(Web Server issue):W327-W331.

41. Cleary AS, Leonard TL, Gestl SA, Gunther EJ: Tumour cell heterogeneity maintained by cooperating subclones in Wnt-driven mammary cancers Nature 2014, 508(7494):113-117.

42. Lim CB, Prele CM, Cheah HM, Cheng YY, Klebe S, Reid G, Watkins DN, Baltic S, Thompson PJ, Mutsaers SE: Mutational analysis of hedgehog signaling pathway genes in human malignant mesothelioma. PLOS ONE 2013, 8(6):e66685

43. Candace E, Carroll SM, Stewart DP, Xiaoxi Ouyang J, Ogden SK: The extracellular loops of Smoothened play a regulatory role in control of Hedgehog pathway activation. Development 2012, 139(3):612-621.

44. Teng X, Dayhoff-Brannigan M, Cheng WC, Gilbert CE, Sing CN, Diny NL, Wheelan SJ, Dunham MJ, Boeke JD, Pineda FJ, Hardwick JM: Genome-wide consequences of deleting any single gene. Mol Cell 2013, 52(4):485-494.

45. Onishi $\mathrm{H}$, Katano M: Hedgehog signaling pathway as a therapeutic target in various types of cancer. Cancer Sci 2011, 102(10):1756-1760.

46. Abidi A: Hedgehog signaling pathway: a novel target for cancer therapy: vismodegib, a promising therapeutic option in treatment of basal cell carcinomas. Indian J Pharmacol 2014, 46(1):3-12.

47. Matsushita S, Onishi H, Nakano K, Nagamatsu I, Imaizumi A, Hattori M, Oda Y, Tanaka M, Katano M: Hedgehog signaling pathway is a potential therapeutic target for gallbladder cancer. Cancer Sci 2014, 105(3):272-280.

doi:10.1186/1746-160X-10-36

Cite this article as: Rui et al:: Smoothened gene alterations in

keratocystic odontogenic tumors. Head \& Face Medicine 2014 10:36.

\section{Submit your next manuscript to BioMed Central and take full advantage of:}

- Convenient online submission

- Thorough peer review

- No space constraints or color figure charges

- Immediate publication on acceptance

- Inclusion in PubMed, CAS, Scopus and Google Scholar

- Research which is freely available for redistribution

Submit your manuscript at www.biomedcentral.com/submit
C) Biomed Central 